Applied Biology, Vol. 33. (Oxford, London, 1964).

19. Hahn, P., and Koldovsky, O.: Utilization of nutrients during Postnatal Development, (Oxford, Pergamon Press, 1966).

20. Hanson, R. W., and Garber, A. J.: Phosphoenolpyruvate carboxykinase. I. Its role in gluconeogenesis. Amer. J. Clin. Nutr., 25: 1010 (1972).

21. Hoy, P. A.: Diuresis in newborn rat given intravenous water or salt solution. Proc. Soc. Exp. Biol. Med., I22: 358 (1966).

22. Illnerova, H.: Urea formation in rats during postnatal development. Biol. Neonat., 9: 197 (1966)

23. Illnerova, H.: The development of arginase and ornithine transcarbamylase activities in the liver of rats. Physiol. Bohemoslov., I5: 19 (1966).

24. Kornhauser, D., Adam, P. A. J., and Schwartz, R.: Glucose production and utilization in the newborn puppy. Pediat. Res., 4: 120 (1970).

25. Lardy, H. A., Foster, D. O., Young, J. W., Shrago, E., and Ray, P. D.: Hormonal control of enzymes participating in gluconeogenesis and lipogenesis. J. Cell. Comp. Physiol., 66: 39 (1965).

26. Miller, S. A.: Protein metabolism during growth and development. In: H. N. Munro: Mammalian Protein Metabolism, pp. 183-233 (Academic Press, New York, 1969).

27. Miller, S. A.: Nutrition in the neonatal development of protein metabolism. Fed. Proc., 29: 1497 (1970).

28. Miller, S. A., and Allison, J. B.: The dietary nitrogen requirements of the cat. J. Nutr., 64: 493 (1958).

29. Miller, S. A., and Dymsza, H. A.: Artificial feeding of neonatal rats. Science, 141: 517 (1963)

30. Munro, H. N.: Role of amino acid supply in regulating ribosome function. Fed. Proc., 27: 1231 (1968).

31. Rogers, Q. R., and Harper, A. E.: Amino acid diets and maximal growth in the rat. J. Nutr.. 87: 267 (1965)

32. Schaub, J., Gutmann, J., and Lippert, H.: Developmental changes of glycolytic and gluconeogenic enzymes in fetal and neonatal rat liver. Horm. Metab. Res., 4: 110 (1972).

33. Short, J., Armstrong, N. B., Zemel, R., and Lieberman, I.: A role for amino acids in the induction of deoxyribonucleic acid synthesis in liver. Biochem. Biophys. Res. Commun., 50: 430 (1973).

34. Tannenbaum, S. R.: The metabolism in vivo of 2,4-dimethylheptanoic acid. Ph.D. Thesis, M. I. T., Cambridge, Mass. (1962).

35. Thorndike, J.: Comparison of the levels of three enzymes in developing livers of rats and mice. Enzyme, 13: 252 (1972).

36. Vavrousek, E.: The involvement of free amino acid pools in the regulation of protein synthesis in the neonatal rat liver (Sc.D. thesis, M. I. T., Cambridge, Mass., 1974).

37. Vavrousek-Jakuba, E., and Miller, S. A.: Effect of starvation on protein synthesis in neonatal rat liver. J. Nutr. 105: 1326 (1975)

38. Vavrousek-Jakuba, E., Miller, S. A., and White, P. K.: Developmental changes in the distribution of rat liver ribosomes in response to dietary manipulation. $\mathbf{J}$. Nutr., 105: 389 (1975).

39. Vernon, R. G., Eaton, S. W., and Walker, D. G.: Carbohydrate formation from various precursors in neonatal rat liver. Biochem. J., 110: 725 (1968).

40. Vernon, R. G., and Walker, D. G.: Changes in activity of some enzymes involved in glucose utilization and formation in developing rat liver. Biochem. J., 106: 321 (1968).

41. Vernon, R. G., and Walker, D. G.: Glucose metabolism in the developing rat Studies in vivo. Biochem. J., 127: 521 (1972).

42. Vernon, R. G., and Walker, D. G.: Gluconeogenesis from lactate in the developing rat. Biochem. J., 127: 531 (1972).

43. White, P. K., and Miller, S. A.: Design of a metabolic cage for infant rats. Lab. Anim. Sci., 25: 344 (1975).

44. Yeung, D., and Oliver, I. T.: Gluconeogenesis from amino acids in neonatal rat liver. Biochem. J., 103: 744 (1967).

45. Yeung, D., Stanley, R. S., and Oliver, I. T.: Development of gluconeogenesis in neonatal rat liver. Effect of triamcinolone. Biochem. J., 105: 1219 (1967).

46. The diet was prepared according to Miller and Allison (28). Composition in grams per kg of dry diet: casein, 250; dextrose, 172; sucrose, 167; dextrine, 172; corn oil, 150; salt mix (31), 40; choline chloride $(50 \% \mathrm{w} / \mathrm{v}), 4 \mathrm{ml}$; agar, 35; distilled water, 1,000; vitamin mix, 10 . Composition of vitamin mix in grams: vitamin $\mathrm{A}$ acetate $+\mathrm{D}_{2}(325,000 \mathrm{IU} \mathrm{A} / 32,500 \mathrm{IU} \mathrm{D}), 2.0$; vitamin E acetate $(250 \mathrm{U} / \mathrm{g}), 80.0$; vitamin $\mathrm{K}, 1.0$; thiamine $\mathrm{HCl}, 2.0$; riboflavin, 4.0 ; niacin, 10.0 ; vitamin $\mathrm{C}, 40.0$; pyridoxine $\mathrm{HCl}, 2.0 ; p$-aminobenzoic acid $(p \mathrm{ABA}), 20.0$; biotin, 0.10 ; Ca pantothenate, 10.0; folic acid, 0.4; inositol, 40.0; vitamin $\mathrm{B}_{12}$, 10.0; sucrose, 1780.54 .

47. Composition in grams per $\mathrm{kg}$ of dry diet: casein, 354 ; dextrose, 41 ; sucrose, 33 ; dextrine. 41; corn oil, 442; remainder as in note (46).

48. New England Nuclear, Boston, Mass.

49. Starvation was imposed for 4,15 , or $48 \mathrm{hr}$, respectively, for the three ages. The rationale for the starvation periods selected is presented under Discussion.

50. Composition in grams: Hammarsten casein, 5.0; nonfat dry milk, 15.0; vitamin mix, 2.0 ; mineral mix, 0.5 ; choline chloride $(50 \% \mathrm{w} / \mathrm{v}), 0.08 \mathrm{ml}$; corn oil, 11.0 ; distilled water, 66.5. Vitamin mix, composition in grams: vitamin A acetate + $\mathrm{D}_{2}\left(325,000 \mathrm{IU} \mathrm{A} / 32,500 \mathrm{IU} \mathrm{D} \mathrm{D}_{2}\right), 0.6000$; vitamin $\mathrm{E}$ acetate, 8.0000; vitamin $\mathrm{K}, 0.0100$; thiamine $\mathrm{HCl}, 0.1060$; riboflavin, 0.8850 ; niacin, 2.2000; vitamin $\mathrm{C}$ 5.2500 ; pyridoxine $\mathrm{HCl}, 0.0756$; $p \mathrm{ABA}, 0.0100$; biotin, 0.0076 ; $\mathrm{Ca}$ pantothenate, 0.8360; folic acid, 0.0025; inositol, 62.3000; vitamin $B_{12}, 2.4800$; glucose, 417.2373. Mineral mix, composition in grams: Ca lactate, 1240.0000; Ca gluconate, 193.5000; KCl, 98.0000; $\mathrm{NaCl}, 68.50000 ; \mathrm{CuSO}_{4} \cdot 5 \mathrm{H}_{2} \mathrm{O}, 0.8630$ $\mathrm{CoSO}_{4} \cdot 7 \mathrm{H}_{2} \mathrm{O}, 0.0240 ; \mathrm{NaF}, 0.0596 ; \mathrm{KI}, 0.0675 ; \mathrm{FeSO}_{4} \cdot 7 \mathrm{H}_{2} \mathrm{O}, 1.5290$; $\mathrm{MgSO}_{4} \cdot 7 \mathrm{H}_{2} \mathrm{O}, \quad 176.5000 ; \mathrm{ZnCl}_{2}, \quad 1.0525 ; \quad\left(\mathrm{NH}_{4}\right)_{6} \mathrm{MO}_{7} \mathrm{O}_{24}, \quad 0.0129 ;$ $\mathrm{MnSO}_{4} \cdot \mathrm{H}_{2} \mathrm{O}, 0.0139$.

51. Delmar Scientific Co., Maywood, Ill.

52. Worthington Biochemicals, Freehold, N. J.

53. The technical assistance of Yukio Ichinose, M. D., in the PEPCK analyses is gratefully acknowledged.

54. Contribution no. 2329 from the Department of Nutrition and Food Science, M.I.T.

55. This research was supported by National Institutes of Health Grant no. GM-10337.

56. Requests for reprints should be addressed to: Patricia K. White, Ph.D., Department of Nutrition, Simmons College, 300 The Fenway, Boston, Mass. 02115 (USA).

57. Accepted for publication October 29, 1975.

\title{
Experimental Analysis of Developing Hemopoiesis in Fetal Bone Marrow
}

\author{
R. J. HAAS, ${ }^{(23)}$ D. HOELZER, E. KURRLE, B. LANDENBERGER, AND U. WINKLER \\ Department of Pediatrics, Hematology Division, University of Munich, Munich, and Department of Clinical Physiology, University of Ulm, \\ Ulm/Donau, Federal Republic of Germany
}

\section{Extract}

1. We have used fetal rats to study the following aspects of the development of hemopoiesis: $(a)$ content of hemopoietic stem cells in fetal bone marrow, liver, and peripheral blood and $(b)$ origin of hemopoietic cells in the developing mammalian bone marrow.
2. In the studies we utilized the diffusion chamber technique to study the content of stem cells committed to granulopoiesis. The number of myelopoietic stem cells in liver peripheral blood and in "bone marrow" of 18-day-old rats is nearly identical. Since in "bone marrow" a considerable number of peripheral blood cells are present in the vessels at that time, whereas extravascular cells con- 
sist only of mesenchymal cells, one might assume that these peripheral blood cells give rise to granulocytic precursors in the cultures. Morphologically these cells are "blast" cells and lymphocytes.

3. Based on cell labeling indices of radioautograms, derived from continuous infusion of pregnant rats with $\left[{ }^{3} \mathrm{H}\right]$ thymidine, it could be shown that in the perichondral area mesenchymal cells of the fetus and newborn have a slow rate of DNA turnover whereas "bone marrow" cells are in an active state of profileration.

4. In further support of this it was also shown that injections of hydroxyurea (an agent which destroys cells in DNA synthesis) has virtually no effect on perichondral mesenchymal cells whereas "bone marrow" cells were completely blocked in their ability to support myelopoietic differentiation in the diffusion chamber implants.

5. The conclusions would therefore be that $(a)$ local perichondral cells, i.e., mesenchymal cells, do not contribute to marrow hemopoiesis, $(b)$ matrix cells of the developing bone marrow cannot reconstitute hemopoiesis, and $(c)$ hemopoietic bone marrow cells develop from migrating peripheral "stem cells," one of the sources being the liver.

\section{Speculation}

The development of mammalian bone marrow hemopoiesis is initiated by circulating blood stem cells. The blood receives the stem cells at this time of development mainly from the liver. The morphology of the expanding stem cell population in embryogenesis varies between small mononuclear lymphocyte-like cells and "blast" cells.

Three main hemopoietic sites have been described in the fetus and embryo: the yolk sac, the liver, and the bone marrow $(8,14)$.

Organogenesis of bone marrow in the long bones starts in rats at the 19th day of embryonic life. The first phase consists of the immigration of perichondral cells into the marrow cavity left by degenerated cartilage. The cells in the perichondral area are at that time mesenchymal cells. Together with these cells fine vessels penetrate through windows of the corticalis branching into the cavity. Marrow hemopoiesis is preceded on the 20th day by infiltration of small mononuclear cells and undifferentiated blast cells surrounding thin walled vessels. The first recognizable hemopoietic precursor cells, i.e., erythroblasts, myeloblasts, or megakaryocytes, are present in the rat at the 22 nd day of gestation. Since colonization of the marrow cavity by immigration of mesenchymal cells precedes the establishment of hemopoiesis, the classic theory of Maximow assumes that hemopoietic cells originate from perichondral cells $(11,12)$.

Metcalf and Moore (13), however, contradict this theory. They studied in parabiotic experiments the marrow development in chick embryos using a sex chromosome marker. The results of these studies suggested a migration of hemopoetic stem cells from yolk sac to the liver and later from the liver via peripheral blood into the bone marrow. Further evidence for this hypothesis in the mammalian organism is that during the development of hemopoiesis there exists a high content of migrating stem cells in peripheral blood $(2,9,16)$.

These considerations have led us to an experimental analysis of developing rat bone marrow employing the diffusion chamber technique. From the observations certain conclusions appear justified with respect to the identity and origin of embryonic stem cells.

\section{MATERIAL AND METHODS}

\section{ANIMALS}

The experiments were carried out using 4-month-old female rats of the inbred strain Lew F 134 (Wistar Institute) of an average body weight of $180 \mathrm{~g}$. The ovulation time and the time of fertilization after mating with male rats of the same strain were determined by evaluation of vaginal smears (17).
Continuous $H^{3}-T d R$ Infusion: Group I. $\left[{ }^{3} \mathrm{H}\right]$ Thymidine $\left(\left[{ }^{3} \mathrm{H}\right]-\right.$ TdR (22)) was infused continuously into the tail vein of pregnant rats via a polyethylene catheter (modified method of Little (10)) beginning on day 16 of pregnancy. The amount of $\left[{ }^{3} \mathrm{H}\right] \mathrm{TdR}$ administered per day was $1.6 \mu \mathrm{Ci} / \mathrm{g}$ body weight dissolved in $1 \mathrm{ml}$ $0.9 \% \mathrm{NaCl}$. The specific activity of $\left[{ }^{3} \mathrm{H}\right] \mathrm{TdR}$ was $2 \mathrm{Ci} / \mathrm{mM}$.

This group consisted of eight pregnant rats. Two of the mothers were infused continuously until day 19 of pregnancy, two until day 20 , two until day 21 , and two until term at day 22

The offspring of these animals were killed $1 \mathrm{hr}$ or 10 days after discontinuation of $\left[{ }^{3} \mathrm{H}\right] \mathrm{T} d \mathrm{R}$ infusion, five animals at each point of investigation. From the femora histologic sections were prepared. Autoradiographs were done by the dipping technique using Ilford L4 liquid emulsion. Exposure time was 45 days, and the slides were stained with hematoxylin-eosin. Evaluation of the percentage of labeled mesenchymal cells in the perichondral zone and the cells in the bone marrow cavity was based on at least 500 cells in each section. Autoradiographs of unlabeled sections showed that background was less than 5 grains/cell. Labeled cells were therefore considered to be cells with 5 or more grains.

Inhibition of DNA Synthesis and Cell Death by Treatment with Hydroxyurea: Group II. An additional five pregnant rats received injections intraperitoneally on day 19 of gestation with $2 \times 500$ $\mathrm{mg} / \mathrm{kg}$ body weight hydroxyurea (HU) in $0.9 \% \mathrm{NaCl}$ solution with an 10 -hr interval. One hour after the last $\mathrm{HU}$ injection the pregnant rats received intraperitoneally $2.0 \mu \mathrm{Ci}\left[{ }^{3} \mathrm{H}\right] \mathrm{TdR} / \mathrm{g}$ body weight (specific activity $2.0 \mathrm{Ci} / \mathrm{mM}$ ). One hour after injection 25 embryos from different injected mothers were removed by cesarean section and were prepared for autoradiography. The autoradiograms were prepared as in group $I$. In bone marrow smears at least 500 cells were evaluated for cytologic identification. The classification of cells was carried out according to the method of Harris and Burke (7).

The offspring of the remaining three mothers were removed at day 20,21 , or 22 . Bone marrow smears were prepared for cytologic identification of at least 500 cells in each slide. Autoradiographs of unlabeled smears showed that background was less than 3 grains/cell. Labeled cells were therefore considered to be cells with 3 or more grains.

Diffusion Chamber Technique: Group III. The diffusion chamber technique was that of Boyum and Borgstrom (4). In brief, bone marrow, liver, and peripheral blood cells from the $18 \mathrm{th}, 19 \mathrm{th}$, and 21 st days of embryonic development were cultured for 6 days in diffusion chambers in the abdominal cavity of rats preirradiated with 750 rads. Preirradiation of the host results in a higher cell concentration after culturing in the chambers (5).

Femora were removed from rat fetuses and explanted with their surrounding perichondral zone after removing the muscles under a dissectin microscope. Each ,femur was dissected, the clumps disrupted with fine Pasteur pipettes, and the cell suspension then passed through a stainless filter of $150 \mu \mathrm{m}$.

The cells concentration was determined in a hemocytometer and the cell suspension diluted to the desired concentration of $5 \times 10^{6}$ cells/ml in buffered medium TC 199 (4). Liver cell suspension were prepared in the same way after disruption with Pasteur pipette, $5 \times 10^{6}$

Peripheral blood was collected from the aorta in hematocrit capillaries and the nucleated cell suspension was collected after centrifugation. The concentration was adjusted to $1 \times 10^{6}$ cells $/ \mathrm{ml}$. The diffusion chambers were filled with $100 \mu 1$ of the cell suspension, i.e., $5 \times 10^{5}$ femoral or liver cells, $1 \times 10^{5}$ peripheral blood cells. Four chambers were implanted in each rat. Chambers were harvested after $1,2,3,4,5$, and 6 days, four chambers at each time.

Total cell counts per chamber were determined according to the technique of Boyum and Borgstrom (4) and smears of chamber contents were stained with May Grünwald-Giemsa and peroxidase for differential counts on 500 cells/chamber.

Diffusion Chamber Technique with Hydroxyurea-pretreated Cells: Group IV. Bone marrow, liver, and peripheral blood cells 
from 21-day-old embryos, the mothers of which had received $2 \times$ $500 \mathrm{mg}$ hydroxyurea in a 10 -hr interval on day 19 of gestation (same regime as in group II) were cultured for 6 days in diffusion chambers in the same way as the animals of group $I I I$.

\section{RESULTS}

\section{GROUP I: PROLIFERATIVE BEHAVIOR OF DEVELOPING BONE MARROW VS. PERICHONDRAL CELLS}

After discontinuation of $\left[{ }^{3} \mathrm{H}\right] \mathrm{T} d \mathrm{R}$ application in all experiments the perichondral cells and the cells of the bone marrow cavity were labeled $100 \%$ in the fetuses. When the rate of dilution of label is followed as an indication of cell proliferation the bone marrow cavity cells have a rapid dilution rate of labeling and therefore a comparatively rapid turnover. The only cell types labeled in the bone marrow cavity 10 days after the last $\left[{ }^{3} \mathrm{H}\right] \mathrm{TdR}$ application are "matrix cells" (Fig. 1). The cells of the perichondral area lose their label more slowly, which can be taken as evidence of their slow turnover. From Figure 1 it can also be concluded that the population of slowly turning over perichondral cells increases from day 19 of pregnancy through birth.

\section{GROUP II}

Table 1 shows the distribution of the different nucleated cells in the developing bone marrow cavity of the rat under physiologic conditions and after treatment of the animals with hydroxyurea at day 19 of gestation. In the controls between days 19 and 20 more than two-thirds of the nucleated cells in the bone marrow cavity are undifferentiated reticular cells, osteoblasts, and endothelial cells ("matrix" cells). The remainder are undifferentiated small mononuclear cells with the characteristics of lymphocytes or lymphoid cells and some roundish elements, with a cell diameter of $15 / \mu \mathrm{m}$, which can be classified as undifferentiated blast cells.

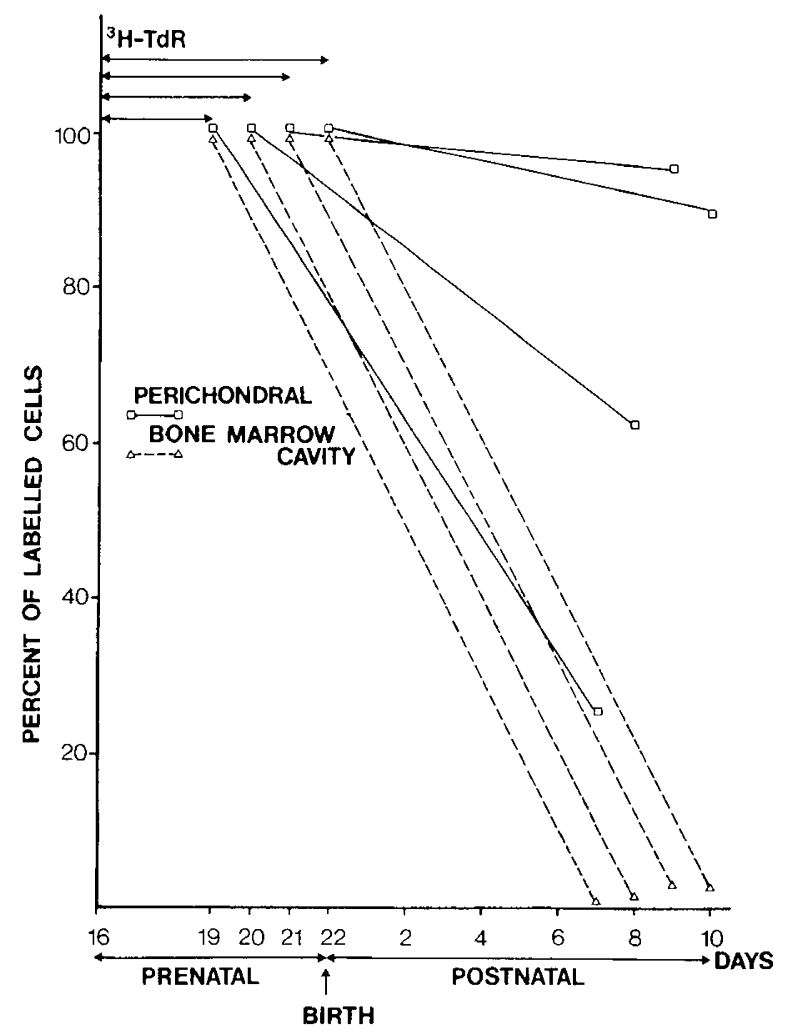

Fig. 1. Labeling index of perichondral cells and bone marrow cavity cells as a function of time. The duration of continuous $\left[{ }^{3} \mathrm{H}\right]$ thymidine $\left({ }^{3} \mathrm{H}-\mathrm{TdR}\right)$ application is indicated. The decrease of labeling index represents the velocity of cell turnover.
There are also small numbers of mature granulocytes and normoblasts. At days 21 and 22 the relative content of matrix cells decreases, whereas the number of blasts, lymphocytes, mature erythroblasts, and granulocytes increases proportionally. The first definitive hemopoietic precursor cells, i.e., erythroblasts $\left(\mathrm{E}_{1}-\mathrm{E}_{2}\right)$, myeloblasts/myelocytes $\left(M_{1}-M_{4}\right)$, or megakaryocytes, are visible at term on the 22 nd day.

In the controls, after a flash injection of $\left[{ }^{3} \mathrm{H}\right]$ thymidine, between $20 \%$ and $30 \%$ labeled bone marrow cavity cells were seen at the different time points between days 19 and 22 of prenatal development.

Fractionated injections of $\mathrm{HU}$, given to the mothers at day 19 of pregnancy, produce within 2 days a complete destruction of all bone marrow cavity cells in the offspring with the exception of the matrix cells (see Table 1). It could be shown in histologic section made at the same time that the perichondral area was undamaged. At day 22, i.e., 3 days after the last HU injection, some blast cells and lymphocytes can be detected. However, hemopoietic precursor cells $\left(E_{1}-E_{2}, M_{1}-M_{4}\right.$, megakaryocytes) are still not present. It could be shown (not listed in Table 1) that the latter cells were present again in bone marrow 2 days after birth.

One hr after the last $\mathrm{HU}$ injection there was no evidence for an uptake of $\left[{ }^{3} \mathrm{H}\right] \mathrm{TdR}$ in marrow, liver, and peripheral blood; i.e., not a single cell nucleus could be found to be labeled.

\section{GROUP III: IN VITRO GROWTH OF GRANULOCYTIC COLONIES IN DIFFUSION CHAMBER METHOD}

We utilized the diffusion chamber method (4) to study the number of myelopoietic cells in liver, bone marrow, and peripheral blood on the 18th, 19th, and 21 st days of gestation of rats. The myelopoietic cells which grow after some days of culture are derived from hemopoietic stem cells and therefore are an indication of the presence of hemopoietic precursor cells in the cell suspension before culturing. Figure 2 shows the results. The number of myelocytic cells, as determined by the peroxidase staining method, is given per diffusion chamber as function of time after implantation of liver cells, of bone marrow cells, and of peripheral blood cells. The increase of myelocytic cells per chamber is highest between days 3 and 5 for cells derived from 18th day bone marrow and blood. A similar increase in the number of myelocytic cells is seen for bone marrow and blood cells, derived from animals of 19 th and 21 st days of gestation. At the 18 th day and the 21 st day the original cell inoculum of peripheral bloodderived cells in the chambers was markedly lower than the cell inoculum prepared from "bone marrow." Finally, there is no evidence for a significant proliferation of myelocytic cells derived from liver cell suspension up to the 21 st day.

\section{GROUP IV: IN VITRO GROWTH OF GRANULOCYTIC COLONIES IN DIFFUSION CHAMBER AFTER TREATMENT WITH HU}

Bone marrow, liver, and peripheral blood cells from 21-day-old embryos, the dams of which had received fractionated injections of hydroxyurea at day 19 , were put into diffusion chambers. The same cell numbers as in the experiments of group $I I I$ were implanted. Morphologically at the time of implantation in "bone marrow" only matrix cells could be detected. In the liver $90 \%$ of the cells were liver cells and only $10 \%$ were hemopoietic cells. No mitoses could be detected (the normal range of hemopoietic cells in 21-day-old rats is $60 \%$ ).

In Figure 3 the total cell number and in Figure 4 the number of myelocytic cells as determined by the peroxidase staining method are given per diffusion chamber as a function of time after - implantation of liver cells, bone marrow cells, and peripheral blood cells. There was no development of myelocytic cells in chambers seeded with "bone marrow cells." Some myelocytic cells are seen in chambers which were implanted with liver cell suspensions or cells from peripheral blood taken from 21-day-old embryos; however, no increase of myelocytic cells is noted. 
Table 1. Distribution of different nucleated cells in developing rat bone marrow of controls and after fractionated injection of hydroxyurea given at day 19 (group II) (SE is indicated $)^{1}$

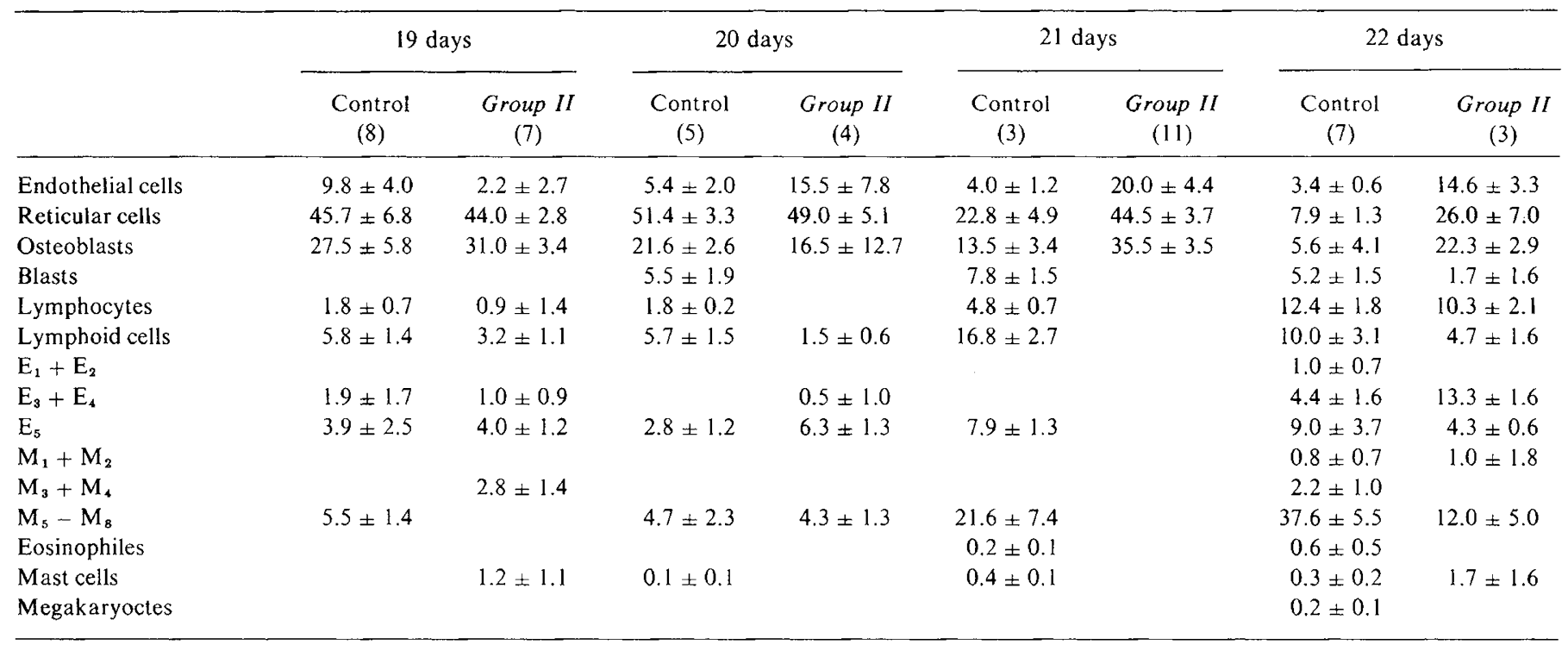

${ }^{1}$ For the erythropoietic series five classes, $E_{1}-E_{5}(7)$, and for the myelopoietic series eight classes, $M_{1}-M_{8}(6)$, were identified.

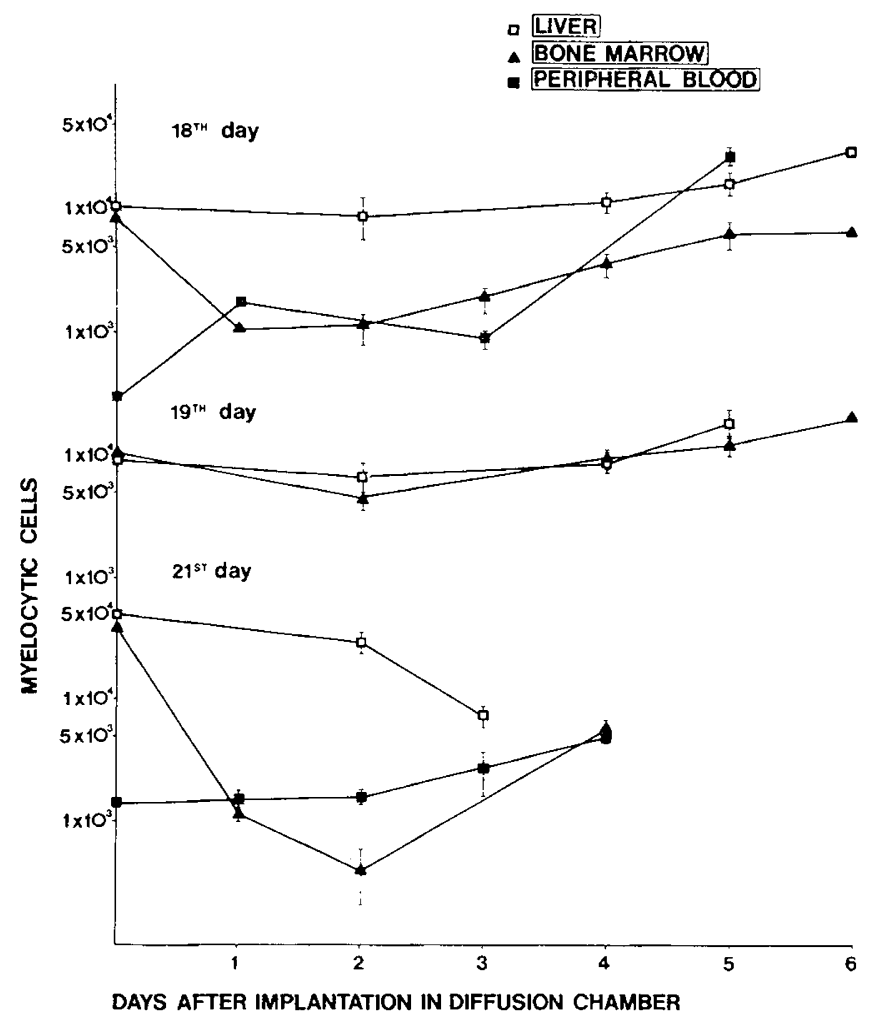

Fig. 2. Number of myelocytic cells as determined by peroxidase staining per diffusion chamber as a function of time for liver cells, bone marrow cells, and peripheral blood cells. Cells were obtained from rat fetuses at the 18th, 19th, and 21st day of gestation and implanted in the chambers (SE is indicated).

\section{DISCUSSION}

Morphologic study of the developing bone marrow in the mammalian organism was one of the predominant fields of early hematologists in the search to find the hematologic "stem cell" ( 3 , $6,8,11,12,19)$. The extensive work of Maximow in 1927 (14) postulating the organogenesis of bone marrow from local undifferentiated mesenchymal cells is still the concept of most of the

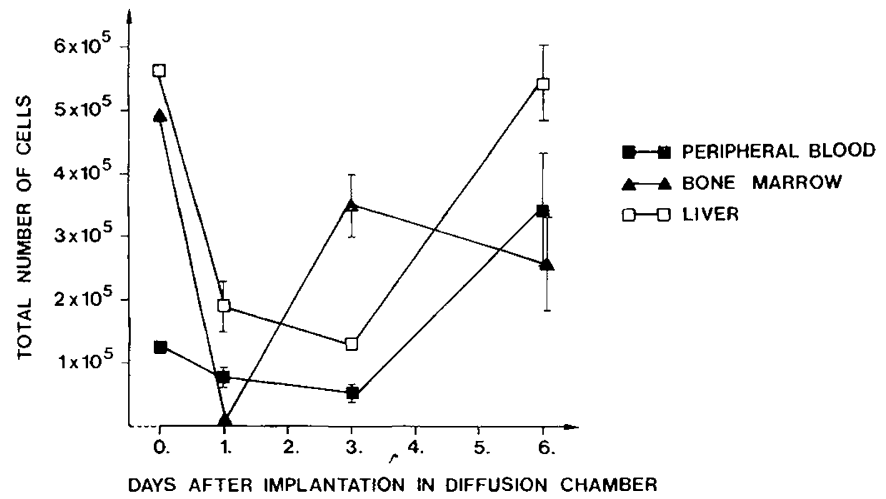

Fig. 3. Total cell number per diffusion chamber as a function of time after implantation of bone marrow, liver, and peripheral blood cells from 21 -day-old fetuses. Fractionated injections of hydroxyurea were given at day 19 (see text (SE is indicated)?

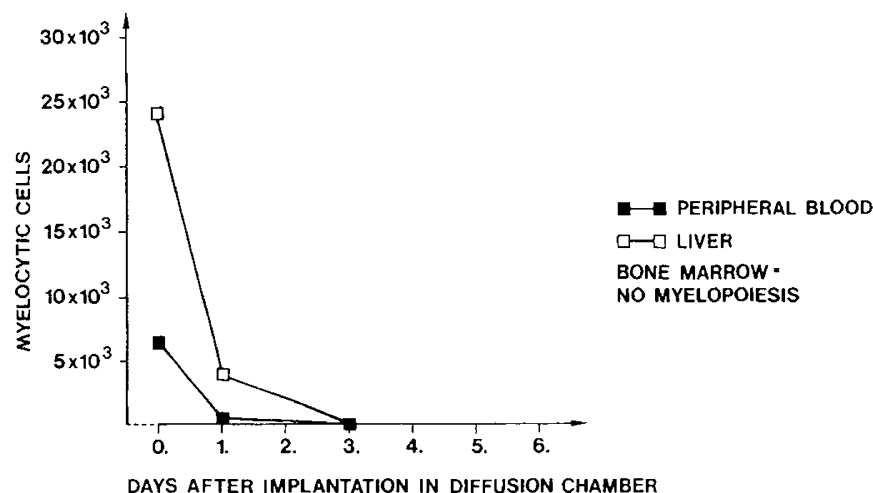

Fig. 4. Number of myelocytic cells as determined by the peroxidase staining method of the total cell number values in Figure 4.

modern hematologists. However, it is generally accepted that during fetal life blood myelopoietic progenitor cells (CFU-C) exist, and that even in postnatal life migratory hemopoietic stem cells are found in the peripheral blood $(1,2,9)$. In the mouse fetus the number of circulating stem cells is much higher than in the adult (16). 
Furthermore, from the parabiotic experiments in chick embryos of Metcalf and Moore (13), there was an indication that hemopoietic stem cells migrate from yolk sac to liver and from the liver subsequently via the peripheral blood stream into the marrow.

In our studies we have made a new approach to estimate the stem cell concentration using the diffusion chamber technique to demonstrate the presence of stem cells committed to granulopoiesis in bone marrow, liver, and peripheral blood. If no stem cells are present in a diffusion chamber, no myelopoietic cells are found after some days of culture. This definition of Bøyum et al. (5) is a necessary prerequisite for our experiments. Since mature granulocytes are unable to proliferate and have a maximal life span of 3 days the presence of myelopoietic cells after 5 days of culture is an indication for hemopoietic precursor cells which have differentiated within 5 days into myelopoiesis.

As could be shown, the increase in number of myelopoietic cells in peripheral blood and bone marrow from 18th and 21 st day of embryonal development is nearly identical, although by technical reasons the original number of peripheral blood cells implanted was markedly lower than that of bone marrow cells. Fetal liver cells of days 18 and 19 of development differentiate into myelopoiesis. Because at the 18 th day of development in bone marrow a considerable number of peripheral blood cells are present in the vessels whereas extravascular cells consist only of mesenchymal cells and cartilage, one might assume that these peripheral blood cells give rise to granulocytic precursors in the cultures. Morphologically, the peripheral blood cells at that time are "blast" cells and lymphocytes. One of the sources for peripheral stem cells is apparently the liver at day 18 to day 19.

Further evidence for migrating stem cells could be obtained by experiments using hydroxyurea. The effect of this agent is an inhibition of DNA synthesis (15). The interval of $10 \mathrm{hr}$ for the HU injections was chosen according to experiments of Scott et al. (18). They showed that after injection, elevated levels of HU in pregnant rats could be measured in the embryonic plasma for a longer period than in maternal plasma. The minimal concentration $\left(10^{-4}\right.$ M) for inhibition of DNA synthesis was present in the embryonic plasma during $8 \mathrm{hr}$, whereas, in dams, it was present for only $4 \mathrm{hr}$.

Based on cell labeling indices of radioautograms derived from continuous infusion of pregnant rats with $\left[{ }^{3} \mathrm{H}\right]$ thymidine, it could be shown that perichondral mesenchymal cells of the fetus and newborn have a slow rate of DNA turnover, whereas "bone marrow" cells are in an active state of proliferation. In further support of this, it was also shown that hydroxyurea has virtually no effect on marrow mesenchymal cells whereas "bone marrow" cells are drastically vulnerable and blocked in their ability to support myelopoietic differentiation in diffusion chamber implants.

The conclusions would therefore be that $(l)$ local perichondral cells, i.e., mesenchymal cells, do not contribute to marrow hemopoiesis, that (2) matrix cells of the developing bone marrow cannot reconstitute hemopoiesis, and that (3) hemopoietic bone marrow cells develop from migrating peripheral "stem cells," one of the sources being the liver.

\section{SUMMARY}

We have studied in a series of fetal rats the question of origin of hemopoietic bone marrow cells. The bone marrow development starts at the 19th day with the immigration of perichondral mesenchymal cells together with fine vessels into the marrow cavity. The first detectable hemopoietic cells are lymphocytes and "blasts" at the 20th day. When the labeling pattern of mesenchymal cells and cells of "bone marrow" after a continuous infusion of $\left[{ }^{3} \mathrm{H}\right]$ thymidine was studied, the results indicate a slow DNA turnover of mesenchymal cells and a rapid cell proliferation of developing hemopoietic bone marrow cells.

We utilized the diffusion chamber technique to study the content of granulocytic stem cells in bone marrow, peripheral blood, and liver cells of fetal rats. The stem cell content of peripheral blood and bone marrow and liver was nearly identical at the time when marrow hemopoiesis is initiated.

Fractionated injections of hydroxyurea produced a complete destruction of proliferating cells in the marrow cavity, whereas the perichondral mesenchymal cells were not affected. Since "bone marrow" cells from 21-day-old embryos pretreated with hydroxyurea in the diffusion chambers developed no hemopoiesis, the conclusion would be that $(l)$ local perichondral mesenchymal cells do not contribute to marrow hemopoiesis and (2) hemopoietic bone marrow cells develop from migrating peripheral stem cells.

\section{REFERENCES AND NOTES}

1. Barnes, D. W. H., Ford, E. E., and Loutit, J. F.: Hemopoietic stem cells. Lancet, 2: 1395 (1964).

2. Barnes, W. H., and Loutit, J. F.: Hemopoietic stem cells in the peripheral blood Lancet, 2: 1138 (1967).

3. Bloom, W.: Embryogenesis of mammalian blood. In: H. Downey: Handbook of Hematology, Vol. 1, p. 865 (P. B. Hoeber, Inc., New York, 1938).

4. Bøyum, A., and Borgstrom, R.: The concentration of granulocytic stem cells in mouse bone marrow, determined with diffusion chamber technique. Scand. J. Haematol., 7: 294 (1970).

5. Bøyum, A., Carstensen, A. L., Laerum, O. D., and Cronkite, E. P.: Kinetics of cell proliferation of murine bone marrow cells cultured in diffusion chambers. Blood, 40: 174 (1972).

6. Cronkite, E. P., and Fliedner, T. M.: Granulocytopoiesis. N. Engl. J. Med., 270: 1347, 1403 (1964).

7. Cronkite, E. P., Fliedner, T. M., Killmann, S. A., and Rubini, J. R.: Tritium labeled thymidine $\left({ }^{3} \mathrm{H}-\mathrm{TdR}\right)$. In: Tritium in the Physical and Biological Sciences, Vol 2, p. 189 (Iaea, Vienna, 1962).

8. Hammar, J. A.: Primäres und rotes Knochenmark. Anat. Anz., 19: 567 (1901).

9. Harris, C., and Burke, W. T.: The changing cellular distribution in bone marrow of the normal albino rat between one and fifty weeks of age. Amer. J. Pathol. 33: 1931 (1957).

10. Knoll, W., and Pringel, E.: Der Gang der Erythropoese beim menschlichen Embryo. Acta Hematol., 2: 369 (1949).

11. Kundtzen, S.: In vitro growth of granulocytic colonies from circulating cells in human cord blood. Blood, 43: 357 (1974).

12. Little, J. R., Brecher, G., Bradley, T. R., and Rose, S.: Determination of lymphocyte turnover by continuous infusion of $\mathrm{H}^{3}$-thymidine. Blood, 19: 236 (1962).

13. Maximow, A.:- Über die Entwicklung der Blut. und Bindegewebszellen beim Säugetierembryo. Folia Hematol. (Leipzig), 4: 611 (1907)

14. Maximow, A.: Bindegewebe und blutbildende Gewebe. In: W. von Möllendorff: Handbuch der mikroskopischen Anatomie des Menschen, Vol. 2, Part 1, p. 232 (Julius Springer, Berlin, 1927).

15. Metcalf, D., and Moore, M. A. S.: Hemopoietic Cells, pp. 222-270 (North-Holland Publishing Company, Amsterdam, 1971).

16. Moore, M. A. S., and Metcalf, D.: Ontogeny of the hemopoietic system: Yolk sac origin of in vivo and in vitro colony forming cells in the developing mouse embryo. Brit. J. Hematol. 18: 279 (1970)

17. Philips, F. S., Sternberg, S. S., Schwartz, H. S., Cronin, A. P., Sodergren, J. E., and Vidal, P. M.: Hydroxyurea. 1. Acute cell death in proliferating tissues in rats. Cancer Res., 27: 61 (1967).

18. Pozzi, L. V., Andreozzi, U., and Silini, G.: Colony-forming units in fetal spleen and peripheral blood. Acta Hematol., 48: 337 (1972).

19. Preissecker, E.: Der Genitalzyclus der Nager. In: M. P. Cohrs, R. Jaffé, and H. Meesen: Pathologie der Laboratoriumstiere, p. 419 (Springer, Berlin, Göttingen, 1953).

20. Scott, W. J., Ritter, E. J., and Wilson, J. G.: DNA synthesis inhibition and cell death associated with hydroxyurea teratogenesis in rat embryos. Develop. Biol., 26: 306 (1971).

21. Schridde, H.: Die Entstehung der ersten embryonalen Blutzellen des Menschen. Zbl. Allg. Pathol., 18: 823 (1907).

22. The Radiochemical Centre, Amersham, England. This research was supported by Sonderforschungs-Gereich Contract no. 112, Project $A_{1}$ of Deutsche Forschungsgesellschaft.

23. Requests for reprints should be addressed to: R. J. Haas, M.D., Department of Pediatrics, Hematology Division, University of Munich, 80 Muichen, Lindwurm 4, Federal Republic of Germany.

24. Accepted for publication October 29, 1975. 